\title{
PENGARUH LINGKUNGAN KELUARGA DAN EFIKASI DIRI TERHADAP MOTIVASI BERWIRAUSAHA PADA MAHASISWA FAKULTAS EKONOMI UNIVERSITAS NEGERI JAKARTA
}

\author{
Siti Nur Aini \\ siti_15@feunj.ac.id \\ Fakultas Ekonomi, Universitas Negeri Jakarta \\ Dedi Purwana \\ dpurwana@unj.ac.id \\ Fakultas Ekonomi, Universitas Negeri Jakarta \\ Ari Saptono \\ saptono.fe@unj.ac.id \\ Fakultas Ekonomi, Universitas Negeri Jakarta
}

\begin{abstract}
This study aims to analyze the influence of family environment and selfefficacy on entrepreneurial motivation. The method used in this research was ex-post facto with correlational approach. The data was collected using questionnaires distributed to 74 students of Faculty of Economics, Universitas Negeri Jakarta. Path Analysis was used for analyzing the data. This study reveals that; 1) family environment directly affects entrepreneurial motivation $(p=0.581) ; 2)$ self-efficacy directly influences entrepreneurial motivation $(p=0.538)$, and 3$)$ family environment directly affects self-efficacy $(p=0.380)$.
\end{abstract}

Keywords: entrepreneurial motivation, family environment, self-efficacy, path analysis 


\section{PENDAHULUAN}

Wirausaha mempunyai peran penting dalam memajukan perekonomian Negara. Manfaat adanya wirausaha ialah dapat mengurangi angka pengangguran dan mengurangi tingkat kemiskinan. Inilah yang Indonesia butuhkan saat ini yaitu wirausaha. Tetapi wirausaha di Indonesia masih dinilai rendah karena banyaknya pengangguran. Berdasarkan Badan Pusat Statistik (BPS) Tingkat Pengangguran Terbuka (TPT) di Indonesia disumbang oleh tenaga terdidik yaitu para sarjana-sarjana lulusan universitas maupun diploma di Indonesia.

$\begin{array}{ccc} & \text { Berdasarkan data } & \text { Badan } \\ \text { Pusat } & \text { Statistik } & \text { Tingkat }\end{array}$

Pengangguran Terbuka (TPT) Diploma I/II/II naik dari $2,50 \%$ menjadi 2,67\%, dan TPT Universitas naik dari 5,86 menjad $6,83 \%$. Berbeda dengan pendidikan tinggi, TPT menurut pendidikan rendah tercatat menurun. Misalnya, TPT SD ke bawah turun menjadi 16,97\% dari 18,8\%. TPT Sekolah Menengah Pertama (SMP) turun dari $22,80 \%$ menjadi $21,63 \%$.
Adapun, TPT SMA turun dari 25,98\% menjadi $24,86 \%$. Dan TPT Sekolah Menengah Kejuruan turun dari 16,98\% menjadi 15,39\%. Peningkatan yang terjadi pada pengangguran pada kalangan terdidik seperti universitas dan diploma yang cukup besar karena menjadi sarjana ternyata bukan jaminan bisa langsung memperoleh pekerjaan yang diinginkan.

Kurangnya lapangan pekerjaan yang disediakan dari pemerintah membuat pengangguran bertambah. Solusi terbaik untuk mengurangi pengangguran ialah mengembangkan jiwa wirausaha di kalangan para sarjana muda. Karena sarjana muda adalah penerus bangsa yang harus ikut serta memajukan perekonomian Indonesia. Namun kenyataanya jumlah wirausaha di Indonesia masih kalah dibandingkanegara tetangga seperti Malaysia dan Singapura. "Jumlah pengusaha atau wirausaha di Indonesia jauh lebih sedikit, dibandingkan negara lain di Asia Tenggara (ASEAN). Di Singapura, jumlah pengusaha sudah mencapai $7 \%$ (dari jumlah penduduk), Malaysia 5\%, Thailand 
$3 \%$, sedangkan di Indonesia yang jumlah penduduknya besar hanya $1,65 \%$, saat ini ada 4 juta pelaku UKM yang ada di seluruh Indonesia (Wiji Nurhayat, 2015). Selain itu hingga tahun 2015 hanya tercatat 4 juta pelaku UKM di Indonesia. Jumlah pelaku UKM di Indonesia dinilai masih tidak sebanding dengan laju pertumbuhan penduduk berdasarkan Badan Pusat Statistik (BPS) jumlah penduduk di Indonesia hingga tahun 2014 sekitar 252 juta jiwa dan diprediksikan tahun 2015 naik. "Indonesia masuk kategori negara dengan iklim wirausaha paling rendah di dunia berdasarkan The Ernest and Young G20 Entrepreneurship Barometer 2014," tutur Nur Aini (2015). Angkatan kerja di Indonesia masih sangat tergantung kepada lapangan pekerjaan belum bisa membuka lapangan pekerjaan sendiri sehingga angkatan kerja tidak sebanding dengan lapangan pekerjaan yang disediakan.

Sarjana di Indonesia masih sangat ketergantungan pada penyedia lapangan pekerjaan seperi perusahaan besar. Seharusnya pola pikir sarjana Indonesia diubah menjadi para penyedia lapangan pekerjaan, seperti memilih untuk berwirausaha untuk mengurangi pengangguran. Kurangnya wirausaha di Indonesia karena tidak adanya motivasi berwirausaha pada diri sarjana-sarjana di Indonesia untuk memilih berwirausaha sebagai tujuan karir. Banyak yang beminat untuk berwirausaha tetapi motivasi dari dalam diri dan lingkungan sekitar tidak mendukung maka tak jarang yang gagal sehingga tidak bisa sukses dalam berwirausaha.

Motivasi untuk memulai berwirausaha di kalangan mahasiswa sangat rendah karena tidak ada dorongan kuat untuk mahasiswa memilih karir sebagai wirausaha lagipula pola pikir pada mahasiswa setelah lulus yang masih tertuju untuk bekerja di perusahaan-perusahaan dan rendahnya keyakinan pada diri sendiri untuk memulai bisnis. Pemerintah mengupayakan para wirausaha muda dari kalangan mahasiswa untuk memilik karier sebagai wirausaha dengan tujuan mengurangi tingkat pengangguran. 
Rendahnya motivasi berwirausaha juga terlihat pada diri mahasiswa Fakultas ekonomi di Universitas Negeri Jakarta, walaupun lulusannya di arahkan ke tenaga pendidik tetapi harus mempunyai dasar berwirausaha juga. Menurut Pembantu Rektor III UNJ "Total mahasiswa UNJ ada 26.000, jika mereka didorong berwirausaha dampaknya akan luar biasa membangun perekonomian Indonesia" Berdasarkan data yang di dapatkan oleh peneliti jumlah mahasiswa yang mengikut Program kewirausahaan mahasiswa (PMW) dinilai masih rendah.

Tabel 1.

Jumlah Peserta Program Mahasiswa Wirausaha (PMW) Universitas Negeri Jakarta Tahun 2014

\begin{tabular}{|l|l|c|}
\hline \multirow{4}{*}{ Angkatan } & Fakultas & $\begin{array}{c}\text { Jumlah } \\
\text { Kelompok } \\
\text { Peserta }\end{array}$ \\
\hline \multirow{4}{*}{2014} & FE & 8 \\
\cline { 2 - 3 } & FT & 11 \\
\cline { 2 - 3 } & FBS & 8 \\
\cline { 2 - 3 } & FIK & 1 \\
\cline { 2 - 3 } & FMIPA & 14 \\
\cline { 2 - 3 } & FIS & 6 \\
\hline \multirow{2}{*}{} & Total Jumlah & $\mathbf{4 8}$ \\
\cline { 2 - 3 } & \multicolumn{2}{|l}{}
\end{tabular}

Sumber data: Program kewirausahaan UNJ
Berdasarkan data diatas mahasiswa yang mempunyai motivasi sehingga berminat untuk mengikuti perlombaan kewirausahaan di tahun 2014 hanya sebesar 48 orang total yang mengkikuti PMW dari berbagai fakultas-fakultas, itu berarti hanya sedikit yang mempunyai motivasi dan berniat untuk mencoba berwirausaha padahal hadiah dari perlombaan tersebut adalah diberikannya modal dari pihak Universitas Negeri Jakarta untuk membuka usahanya tetapi masih saja mahasiswa tidak berminat untuk mencoba membuka usaha.

Berdasarkan data program mahasiswa wirausaha di tahun 2014 pada fakultas ekonomi hanya diikuti 8 kelompok tidak sebanding dengan jumlah mahasiswa Fakultas Ekonomi. Dari 8 kelompok terdiri dari 2 dari Ekonomi dan Administrasi, 4 kelompok dari manajemen dan 2 dari Akuntansi. Padahal fakultas ekonomi sudah memberikan berbagai program untuk menumbuhkan jiwa kewirausahaan dalam mahasiswa- 
nya misalkan ada mata kuliah pendidikan kewirausahaan dan ada program econodot yaitu program berjualan yang dilakukan para mahasiswa. Tetapi kenyataannya mahasiswa fakultas ekonomi masih kurang termotivasi dan berniat mengikuti PMW.

Jumlah wirausaha dikalangan mahasiswa dinilai masih rendah, terlihat dari table 1.2 mahasiswa yang mengikuti program kemahasiswa di fakultas ekonomi. Rendahnya motivasi dalam diri mahasiswa untuk terjun ke dalam usaha bisnis, Sehingga berimbas pada alumni yang lebih banyak untuk menjadi karyawan dibandingkan membuka usaha sendiri. Rendahnya mahasiswa yang terdorong mengikuti lomba PMW berimbas pada jumlah alumni Fakultas Ekonomi tahun 2012 sampai dengan 2014 yang berwirausaha hanya sedikit dibandingkan yang bekerja sebagai karyawan di suatu perusahaan, guru maupun pengangguran. Padahal yang dibutukan Indonesia saat ini adalah seserang yang bisa membuka usahanya sendiri sehingga mengurangi pengangguran dan menambah lapangan pekerjaan di Indonesia bukan bergantung pada perusahaanperusahaan yang nantinya mengalami kebangkrutan.

Tabel 2.

Jumlah Alumni Fakultas Ekonomi yang Berwirausaha

\begin{tabular}{|c|c|c|c|c|c|}
\hline \multirow{2}{*}{ Tahun } & \multirow{2}{*}{ Jumlah } & \multirow{2}{*}{ Wirausaha } & \multicolumn{3}{|c|}{ Tidak Menjadi Wirausaha } \\
\cline { 5 - 6 } & & & & \multicolumn{3}{|}{} \\
\cline { 5 - 6 } & Lulusan & & Karyawan & Guru & Pengangguran \\
\hline 2012 & 286 & 3 & 248 & 25 & 10 \\
\hline 2013 & 317 & 3 & 286 & 18 & 10 \\
\hline 2014 & 324 & 2 & 284 & 28 & 10 \\
\hline \multicolumn{2}{|l|}{ Jumlah } & 8 & 818 & 71 & 30 \\
\hline
\end{tabular}

Sumber: Career Development Center (CDC FE UNJ)

Table 1.3 diatas menje- Ekonomi Universitas Negeri Jakarta laskan, pada tahun 2012 sampai 2014 jumlah lulusan dari Fakultas semakin meningkat tetapi jumlah alumni fakultas ekonomi yang 
berwirausaha masih dinilah rendah, karena di tahun 2012 dari 286 mahasiswa yang lulus hanya 3 orang diantaranya memilih karier sebagai wirausaha selebihnya menjadi karyawan, guru dan pengangguran. Pada tahun 2014 ada peningkatan jumlah mahasiswa yang lulus dari fakultas ekonomi yaitu sebesear 324 mahasiswa namun pada tahun ini juga terjadi penurunan jumlah alumni yang memilih karier sebagai wirausaha yaitu hanya ada 2 orang dari 3 orang tahun 2012-2013 dapat disimpulkan dari data tersebut adalah rendahnya tingkat keinginan mahasiswa setelah lulus dari bangku perkuliahan untuk memiliki karier sebagai wirausaha karena motivasi untuk menjadi karyawan sangat besar.

Berdasarkan data di atas, menunjukkan rendahnya alumni Fakultas Ekonomi yang memilih karier sebagai wirausaha karena di dalam diri alumni Fakultas Ekonomi tidak mempunyai motivasi yang kuat untuk berwirausaha. Hal ini akan membuat mereka setelah lulus dari bangku perkuliahan belum memiliki pekerjaan sehingga membuat jumlah pengangguran bertambah. Penting sebuah motivasi berwirausaha saat masih dibangku perkuliahan karena akan menumbuhkan niat untuk berwirausaha ketika lulus dari bangku perkuliahan. Rendahnya motivasi berwirausaha pada diri dipengaruhi oleh beberapa faktor. Menurut Buchari Alma bahwa ada 3 faktor yang mempengaruhi seseorang membuka usaha yaitu, personal menyangkut kepribadian seseorang, sociological menyangkut masalah hubungan dengan keluarga, teman, dan environmental menyangkut hubungan dengan lingkungan (Alma Buchari, 2011:9).

Kepribadian seseorang sangat menentukan tingkat keberhasilan yang akan dirainnya. Kepribadian yang harus dimiliki seseorang seperti efikasi diri dan Locus of control. Efikasi diri adalah salah satu kepribadian yang harus dimiliki 
seseorang ketika seseorang ingin merasakan kesuksesan. Seseorang yang ingin berwirausaha harus mempunyai efikasi diri yang tinggi. Efikasi diri adalah suatu keyakinan yang ada dalam diri seseorang yang mempengaruhi besarnya motivasi. Efikasi diri sangatlah penting untuk seseorang karena suatu keyakinan pada diri seseorang sangat berguna di masa depan. Seseorang yang ingin memulai berwirausaha perlu mempunyai keyakinan pada dirinya bahwa dirinya mempunyai kompetensi yang baik untuk melakukan usaha sendiri. Sonny Sumarsono mengemukakan "Sebagai wirausaha sangat penting untuk mengenal kekuatan dan kelemahan dirinya"(Sumarsono, 2010:13). Karena bagi wirausaha menyadari kompetensi yang ada dalam dirinya adalah modal utama untuk memulai usahanya dan harus mempunyai semangat yang tinggi untuk tetap bekerja membangun usaha yang diinginkan.
Selain kepribadian lingkungan sekitar pun ikut berperan menjadi pendorong seseorang berwirausaha. Menurut Alma Buchari hubungan keluarga masuk dalam kategori sociological. Lingkungan terdekat seorang anak adalah keluarga dan yang kedua adalah lingkungan masyarakat dan teman. Orang tua yang mempunyai peran utama dari sebuah keluarga dalam menentukan suatu pandangan tentang pemilihan pekerjaan yang diambil anaknya kelak. Pola asuh orang tua menentukan tumbuh kembang seorang anak. Setelah itu masyarakat pun ikut membentuk kepribadian seseorang walaupun secara tidak langsung terlihat.

Dorongan keluarga terutama dari orang tua sangatlah penting dalam menumbuhkan jiwa wirausaha pada anakanaknya. Hal ini karena Orang tua mengajarkan pemahaman tentang wirausaha sebagai pandangan hidup dan orang tua menanamkan sifat kemandiran 
yang melekat dalam diri anakanaknya sejak kecil. Setiap orang tua mempunyai pola asuh yang berbeda-beda untuk mendidik dan membimbing anaknya dalam mengarahkan karier di masa depannya, hal ini berpengaruh terhadap motivasi seseorang untuk berwirausaha. Orang tua yang terlalu tidak peduli dengan pilihan karir seorang anaknya membuat anak menjadi sulit memilih karir yang baik.

Setelah itu teman menjadi faktor pendorong untuk seseorang berwirausaha. Mahasiswa yang ingin berwirausaha tak jarang dibantu oleh teman dengan pencarian modal, tempat usaha, dll. Teman atau sahabat menjadi peran penting buat seseorang dimana mereka dapat berdiskusi tentang ide wirausaha masalah yang dihadapinya dan cara-cara mengatasi masalahnya ketika orang tua tidak mempunyai peranan penting bagi anaknya.

Faktor yang mempengaruhi seseorang untuk memulai usaha adalah environment seperti lingkungan sekolah, kampus, atau tempat kerja. Pada lingkungan kampus seperti di Universitas Negeri Jakarta membangun jiwa wirausaha dikalangan mahasiswa sudah dilakukan pihak kampus, terbukti berbagai kebijakan dari kampus dilakukan melalui berbagai kegiatan rancangan program diantaranya Program Mahasiswa Wirausaha (PMW) dan Gerakan Kewirausahaan Naional (GKN) program ini sangat bermanfaat untuk mendapatkan modal usaha yang dapat diikuti oleh para mahasiswa yang ingin membuka usaha.

Berdasarkan survei awal yang peneliti lakukan melalui observasi dan wawancara pada tanggal 10 januari 2015 dengan beberapa mahasisiwa fakultas ekonomi. Mereka mengatakan masih tidak tertarik untuk berwirausaha setelah lulus kuliah karena menurut mereka orang tua lebih setuju untuk anaknya bekerja sebagai Pegawai Negeri Sipil (PNS) atau karyawan di perusahaan besar yang gaji atau 
pendapatannya sudah tetap. Hal ini menurut mereka sangat mempengaruhi keyakinan mereka untuk tetep berwirausaha.

Universitas Negeri Jakarta adalah salah satu perguruan tinggi yang ikut andil dalam membangun jiwa muda untuk berwirausaha. Universitas Negeri Jakarta dengan semboyan Building Future Leaders yang berarti lulusan dari Universitas Negeri Jakarta diharapkan dapat ikut membangun perekonomian di Indonesia dengan cara semua lulusan Universitas Negeri Jakarta dapat membuka lapangan kerja yang nantinya akan mengurangi pengangguran di Indonesia.

Pihak Universitas Negeri Jakarta khususnya pada Fakultas Ekonomi jurusan ekonomi dan administrasi tidak hanya dapat menghasilkan tenaga pendidik tetapi ikut berperan untuk membangun jiwa wirausaha pada mahasiswanya dengan memberikan pendidikan kewirausahaan yang dibutuhkan para wirausaha muda agar mahasiswa dapat menumbuhkan niat untuk berwirausaha ketika mereka sudah memahami tentang penghetahuan kewirausahaan. Pada sektor pendidikan yang relatif kompetitif akan menumbuhkan manusia yang mempunyai motivasi untuk wira-usaha yang tinggi, sehingga diperlukan adanya pemahaman tentang bagaimana mengembangkan dan mendorong lahirnya wirausahawirausaha muda yang potensial, menjadi manusia yang bisa mengembangkan diri sendiri dan mengembangkan sekitarnya.

Membangun motivasi pada diri mahasiswa sangatlah penting karena akan membentuk kecenderungan niat membuka usahausaha baru. Pada kenyataanya wirausaha bukan hanya seseorang yang memiliki keahlian khusus tetapi seseorang yang harus memiliki kemauan yang kuat untuk memulainya dan tidak pantang menyerah, Indonesia membutuhkan orang yang berjiwa wirausaha tersebut. 
Berbagai gejala diatas yaitu lingkungan keluarga, efikasi diri, dan lingkungan kampus dan teman yang mempengaruhi tingkat motivasi berwirausaha pada diri mahasiswa Fakultas Ekonomi Universitas Negeri Jakarta. Dari semua faktor yang sudah dijelaskan, peneliti tertarik untuk meneliti motivasi berwirausaha pada diri mahasiswa Fakultas Ekonomi di Universitas Negeri Jakarta.

\section{KAJIAN TEORI}

\section{Motivasi Berwirausaha}

Pada seseorang yang ingin berwirausaha diperlukan adanya suatu motivasi yang tinggi pada dirinya yang berguna sebagai pendorong seseorang berwirausaha dan menjadi suatu alasan dasar seseorang memilih karir sebagai wirausaha. Menurut Irham Fahmi "untuk menjadi seseorang wirausahawan memang membutuhkan motivasi tinggi, dengan motivasi yang tinggi tersebut seseorang bisa mengubah hidupnya dari tidak memiliki usaha menjadi memiliki usaha" (Irham Fahmi,2013:12).

Pada negara-negara maju budaya keinginan atau kemauan seseorang menjadi bos lebih besar dibandingkan untuk bekerja pada suatu perusahaan yang milik orang lain. Itu berarti motivasi untuk berwirausaha sudah tertanam di masyarakat yang tinggal di negaranegara maju. Secara estimologi kata motivasi berasal dari bahasa latin yaitu kata "movere" yang berarti "menggerakkan atau to move" (Winardi, 2008:1). Istilah motivasi menurut Hamzah B Uno (2013:12) berasal dari kata motif yang dapat diartikan sebagai kekuatan yang terdapat dalam diri individu yang menyebabkan individu tersebut bertindak atau berbuat.

$$
\text { Menurut Danang (2013:1) }
$$
motivasi adalah sebagai keadaan yang mendorong keinginan individu untuk melakukan kegiatan-kegiatan tertentu untuk mencapai keinginannya dan motivasi yang ada pada seseorang merupakan kekuatan yang akan mewujudkan suatu perilaku dalam mencapai 
tujuan kepuasan dirinya pada tipe kegiatan yang spesifik, dan arah tersebut positif dengan mengarah mendekati objek yang menjadi tujuan".

Dari beberapa pengertian diatas ini dimaksudkan bahwa, motivasi adalah suatu dorongan yang ada pada diri seseorang berupa sebuah keinginan yang ingin ditunjukkan dengan tingkah lakunya untuk mencapai suatu tujuan yang diinginkannya. Dalam menjalani kehidupan seseorang tidak lepas dari adanya motivasi. Sementara motivasi, menurut Malone yang dikutip oleh Uno Hamzah membedakan dua bentuk motivasi yang meliputi motivasi instrinsik dan motivasi ekstrinsik. Motivasi instrinsik adalah motivasi yang timbul tidak memerlukan rangsangan dari luar karena memang telah ada dalam diri individu sendiri, yaitu sesuai dengan kebutuhan, sedangkan motivasi ekstrinsik timbul karena ada rangsangan dari luar.

Suryabrata dikutip oleh Eveline Siregar (2011:49) menga- takan "Motivasi adalah keadaan dalam diri seseorang yang mendorong individu tersebut untuk melakukan aktivitas-aktivitas tertentu guna mencapai tujuan yang diinginkan". Sedangkan menurut Yudrik Jahja (2011:16) motivasi merupakan keadaan dalam diri individu atau organisme yang mendorong perilaku ke arah tujuan yang bersifat internal dan eksternal, adapun motivasi yang sifatnya eksternal terkait dengan pengaruh atau eksistensi orang lain di luar individu, misalnya pengaruh orang tua, guru dan teman yang dapat mendorong seseorang untuk berbuat sesuatu sedangkan motivasi yang sifatnya internal yaitu motivasi yang tumbuh dari dalam diri.

Berdasarkan definisi motivasi diatas dapat diartikan bahwa motivasi adalah kekuatan yang ada pada diri seseorang yang mendorong seseorang melakukan suatu tindakan untuk mencapai suatu tujuan yang diinginkan. Motivasi seseorang timbul dari dua arahan, yaitu dari dalam diri sendiri 
berupa kebutuhan dan dari luar diri seperti lingkungan sekitar. Menurut David MC Clelland yang dikutip dari Robbins (2003:216) "ada tiga macam kebutuhan yang membantu menjelaskan motivasi seseorang, ketiga kebutuhan tersebut adalah: (1) Need for Achievement: Merupakan dorongan untuk mengungguli, berprestasi seperangkat kebutuhan seseorang untuk menjadi sukses dan berhasil; (2) Need for Power: Kebutuhan untuk membuat orang lain berperilaku dalam suatu cara yang orang-orang itu (tanpa dipaksa) akan berperilaku demikian, dan (3) Need for Affilation: Merupakan kebutuhan seseorang untuk bersahabat, menjalain hubungan antar pribadi yang baik dan akrab.
Kebutuhan itulah yang mendesak seseorang untuk melakukan suatu tindakan atau perilaku sehingga terjadi suatu motivasi atau semangat dari dalam diri seseorang untuk meraih apa yang dibutuhkannya. Kata "entrepreuner" atau "wirausaha" dalam bahasa Indonesia merupakan gabungan dari wira (gagah, berani, perkasa) dan usaha (bisnis) sehingga istilah entrepreneur dapat diartikan sebagai orang yang berani atau perkasa dalam usaha/ bisnis. Kemudian menurut Geofferey G. Meredith (2000:67) menjelaskan ciri-ciri dan sifat-sifat yang memberikan cerminan sebuat profil dari wirausaha adalah sebagai berikut:

\begin{tabular}{|l|l|}
\hline \multicolumn{1}{|c|}{ Ciri -ciri } & \multicolumn{1}{c|}{ Watak } \\
\hline Percaya diri & - Optimisme \\
& - Kepribadian yang mantap \\
\hline $\begin{array}{l}\text { Berorientasi tugas dan } \\
\text { hasil }\end{array}$ & - Kebutuhan akan prestasi \\
& $\begin{array}{l}\text { - } \text { - Kerorientasi laba atau hasil } \\
\text { - Tekad dan kerja keras }\end{array}$ \\
\hline - Penuh inisiatif \\
\hline Kengambil risiko & - Kemampuan mengambil risiko \\
& - Sukapada tantangan \\
\hline & - Kemampuan sebagai pemimpin \\
& - Dapat bergaul dengan orang lain \\
\hline
\end{tabular}




\begin{tabular}{|l|l|}
\hline \multicolumn{1}{|c|}{ Ciri -ciri } & \multicolumn{1}{c|}{ Watak } \\
\hline Keorisinilan & - Inovatif \\
& - Kreatif \\
& - Fleksibel \\
& - Serba bisa, menghetahui banyak hal \\
\hline $\begin{array}{l}\text { Berorientasi ke masa } \\
\text { depan }\end{array}$ & - Pandangan kedepan \\
\hline
\end{tabular}

Dapat diartikan wirausaha adalah seseorang yang mempunyai keberanian yang mampu berinovasi sendiri dan melihat suatu peluang untuk melakukan sesuatu yang baru dengan mendirikan usaha yang tujuannya mencari laba. Seorang wirausaha harus mempunyai kepercayaan diri yang tinggi, dapat menyelesaikan tugas dengan baik, jiwa kepemimpinan yang kuat dan semangat yang tinggi untuk memulai usahanya seperti yang diinginkannya.

Wirausaha menurut Drucker yang dikutip oleh Suryana (2006:2) adalah kemampuan untuk menciptakan sesuatu yang baru dan berbeda melalui pemikiran kreatif dan tindakan inovatif demi tercapainya peluang banyak. Sedangkan Menurut Kasmir wirausaha adalah seseorang yang memiliki kemampuan untuk menciptakan sesuatu yang baru, berbeda dari yang lain atau mampu menciptakan sesuatu yang berbeda dengan yang sudah ada sebelumnya. Wirausaha menurut Thomas W. Zimmere yang dikutip oleh Irham, "wirausahawan adalah orang yang menciptakan bisnis baru dengan mengambil risiko dan ketidakpastian demi mencapai keuntungan dan pertumbuhan dengan cara mengidentifikasi peluang dan menggabungkan sumber daya yang diperlukan untuk mendirikannya (Irham Fahmi, 2013:2).

Berdasarkan pengertian tentang wirausaha dapat disimpulkan wirausaha adalah seseorang yang memiliki kemampuan untuk melihat suatu peluang untuk menciptakan usaha bisnis yang baru dengan menyalurkan ide kreatifnya dan inovatif. Seseorang yang mempunyai ide kreatif harus 
dikembangkan. Wirausaha menurut Harris yang dikutip oleh suryana "wirausaha yang sukses pada umumnya adalah mereka yang memiliki kompetensi, yaitu yang memiliki ilmu penghetahuan, keterampilan dan kualitas individual yang meliputi sikap, motivasi, nilainilai pribadi, serta tingkah laku yang diperlukan untuk melaksanakan pekerjaan/kegiatan".

Selanjutnya pendapat dari Hisrich, et.al dalam buku Leonardus menyatakan bahwa terdapat tiga pendekatan wirausaha, diantaranya: (1) Pendekatan ekonom, entrepreneur adalah orang yang membawa sumber-sumber tenaga, material, dan asset-set lain ke dalam kombinasi yang membuat nilainya lebih tinggi dibandingkan sebelumnya, dan juga seseorang yang memperkenalkan perubahan, inovasi/pembaruan, dan suatu order/tatanan atau tata dunia baru; (2) Pendekatan psikolog, entrepreneur adalah betul-betul seseorang yang digerakkan secara khas oleh kekuatan tertentu kegiatan utuk menghasilkan atau mencapai sesuatu pada percobaan, pada penyempurnaan, atau mungkin pada wewenang mencari jalan keluar yang lain, dan (3) Pendekatan seorang pebisnis, entrepreneur adalah seseorang pebisnis yang muncul sebagai ancaman, pesaing yang agresif, sebaliknya pada pebisnis lain sesame entrepreuner mungkin sebagai sekutu/mitra, sebuah sumber penawaran, seseorang pelanggan, atau seseorang yang menciptakan kekayaan bagi orang lain, juga menemukan jalan yang lebih baik untuk memanfaatkan sumber-sumber daya, mengurangi pemborosan dan menghasilkan lapangan pekerjaan baru bagi orang lain yang dengan senang hati untuk menjalankannya.

Pengertian di atas dapat dimaksudkan bahwa wirausaha adalah seseorang yang memiliki motivasi yang tinggi disertai dengan kemampuan berinovasi yang menghasilkan suatu produk yang akan di jual dengan harapan akan mendapatkan keuntungan. Wirausaha yang sukses haruslah 
memiliki motivasi yang tinggi karena motivasi adalah dasar dari semua sikap yang akan diambil oleh wirausaha itu sendiri. Motivasi untuk terus berkembang dan memajukan usahanya harus dimiliki oleh setiap usahawan yang ingin sukses. Motivasi berwirausaha harus ditanamkan sejak dini, karena untuk menjadi wirausaha yang sukses perlu semangat dan optimis yang tinggi untuk memulai suatuusaha.

Menurut Sudaryono (2011: 44), semangat kewirausahaan yang perlu di masyarakatkan dan dibudidayakan baik oleh para pengusaha dan para pemimpin antara lain adalah: (1) Kemampuan kuat untuk berkarya (utamanya di bidang ekonomi) dengan semangat mandiri; (2) Mampu membuat keputusan yang tepat dan berani mengambil risiko; (3) Kreatif dan inovatif; (4) Tekun, teliti, dan produktif; (5) Berkarya dengan semangat kebersamaan dan etika bisnis yang sehat.

Berwirausaha tidak selamanya memberikan hasil yang sesuai apa yang kita inginkan, terkadang ada kendala yang sering dihadapi para wirausahawan, wirausahawan yang sukses dan berhasil dalam pekerjaannya yang memiliki Motivasi yang tinggi untuk tidak pantang menyerah walau gagal. Menurut Suryana ada beberapa ciri wirausahawan yang dikatakan sukses dan berhasil, sebagai berikut: (1) Memiliki Motif berprestasi Tinggi: Seorang wirausaha selalu berprinsip bahwa apa yang dilakukan merupakan usaha optimal untuk menghasilkan nilai maksimal; (2) Memiliki persepktif ke depan: Setiap saat mencapai target, sasaran, atau impian, maka segeralah membuat impian-impian baru yang dapat memacu serta memberi semangat dan antuisme kepada kita untuk mencapainya; (3) Memiliki kreatifitas tinggi: Seorang wirausaha umumnya memiliki daya kreasi dan inovasi yang lebih; (4) Memiliki sifat inovasi tinggi: Seorang wirausaha harus segera menerjemahkan mimpimimpinya menjadi inovasi untuk mengembangkan bisnisnya; Memiliki tanggung jawab: Ide dan 
perilaku seseorang wirausaha tidak terlepas dari tuntutan tanggung jawab, dan (6) Memiliki keberanian menghadapi risiko: Seorang wirausaha harus berani menghadapi risiko. Semakin besar risiko yang dihadapinya, semakin besar pula kesempatan untuk meraih keuntungan.

Seseorang membutuhkan sebuah motivasi untuk meraih citacitanya. Ketika seseorang ingin terjun ke dunia usaha dibutuhkan motivasi yang tinggi karena untuk menjadi wirausaha yang sukses tidak mudah karena banyak rintangan yang akan dilaluinya. Peran dari sebuah motivasi adalah sebagai pendorong sebelum melakukan tindakan.

Membentuk seseorang yang berjiwa wirausaha dan mampu melakukan tindakan wirausaha maka yang harus tertanam dahulu adalah sebuah motivasi karena dasar dari sebuah tindakan seseorang berawal dari sebuah motivasi yang disertai tujuan yang ingin dicapainya. Berdasarkan interprestasi dari teori diatas dapat disintesiskan bahwa Motivasi untuk berwirausaha dapat diukur dari motivasi ekstrinsik dan Instrinsik. Motivasi ekstrinsik terdiri dari beberapa indikator yaitu. Keinginan untuk mendapatkan pendapatan yang lebih tinggi, keinginan untuk memilih karier yang lebih memuaskan, keinginan untuk menjadi pribadi yang mandiri, keinginan untuk mendapatkan prestise dengan menjadi pemilik usaha sendiri, keinginan untuk menjalankan idea tau konsep baru, dan Motivasi instrinsik terdiri dari indikator dorongan membantu perekonomian masyarakat, dorongan membuka lapangan pekerjaan.

\section{Lingkungan Keluarga}

Manusia hidup tidak terlepas dari sebuah lingkungan. Saat anak dilahirkan tumbuh kembang seorang anak ada pada lingkungan keluarga, itulah lingkungan pertama atau pendidikan pertama yang dikenal dan dirasakan seorang anak. Maka manusia yang berwirausaha membutuhkan kepribadian yang kuat untuk memajukan 
hidupnya dengan dipengaruhi oleh pendidikan.

Pendidikan dasar yang dirasakan seseorang adalah dari lingkungan keluarga. Karena lingkungan tidak dapat dipisahkan dari kehidupan manusia sejak lahir hingga mati. Menurut Wasty Soemanto "Strategi pendidikan manusia wirausaha mengikuti asas pendidikan seumur hidup, yang berlangsung kapan saja dan dimana saja. Oleh karena itu, maka pendidikan manusia wirausaha dimulai sejak manusia masih mulai hidup dan berkelanjutan yaitu di lingkungan keluarga" (Wasty Soemanto, 2002:95).

Selanjutnya, Alisuf menjelaskan lingkungan dapat diartikan dengan segala sesuatu yang ada di dalam dan di luar diri individu yang bersifat mempengaruhi sikap tingkah laku atau perkembangannya. Lingkungan merupakan salah satu faktor yang mempengaruhi kepribadian seorang anak. Jika seseorang anak diberikan pendidikan secara baik dalam lingkungan maka anak tersebut akan menjadi baik. Sedangkan jika seseorang anak berada pada lingkungan yang kurang baik seperti pendidikan, perhatian orang tuanya, maka anak tersebut biasanya akan menjadi orang yang kurang baik pula.

Berdasarkan uraian pengertian diatas dapat disimpulkan lingkungan terbagi menjadi dua yaitu lingkungan fisik dan sosial dimana kedua lingkungan tersebut dapat mempengaruhi perkembangan individu dengan berinteraksi. Lingkungan dapat mempengaruhi tingkah laku dan memberi rangsangan pada pertumbuhan dan perkembangan seseorang secara individu. Lingkungan memberikan pengaruh dalam kehidupan seseorang menentukan masa depannya. Lingkungan merupakan semua informasi yang diterima manusia melalui alat indera sehingga mempengaruhi perkembangannya yang ditunjukkan dengan sikap dan perilaku seseorang. Lingkungan mempunyai peranan yang sangat penting 
dalam membenuk kepribadian seorang anak.

Pendidikan pertama yang diterima seseorang adalah dari lingkungan keluarga. Tumbuh kembang seorang anak di bawah pengawasan orang tua. Lingkungan keluarga adalah lingkungan pertama seorang anak merasakan. Menurut William J. Goode keluarga adalah satusatunya lembaga sosial yang diberi tanggungjawab untuk mengubah suatu organisme biologis menjadi manusia. Selanjutnya Hasbullah sampai pada kesimpulan bahwa lingkungan keluarga merupakan lingkungan pendidikan yang pertama, karena dalam keluarga inilah anak pertama-tama mendapatkan didikan dan bimbingan.Orang tua mempunyai tanggung jawab untuk memberikan pendidikan dasar kepada anakanaknya melalui aturan yang dibuat orang tua.

Dapat disimpulkan bahwa keluarga menjadi hal yang terpenting dari seseorang. Keluarga merupakan lingkungan pendidikan yang pertama karena seseorang anak yang baru lahir mulai mendapat pelajaran dari lingkungan keluarga yaitu dari orang tuanya. Dalam lingkungan keluarga segala sikap, tingkah laku kedua orang tua sangat berpengaruh terhadap perkembangan anak. Penjelasan Imam Barnadid "lingkungan keluarga merupakan lingkungan yang merasa bertanggungjawab atas kelakuan, pembentukan kepribadian, kasih sayang dan bimbingan, kesehatan dan suasana rumah.

Sunarto (2002:193) menjelaskan keluarga merupakan lingkungan pendidikan yang pertama dan utama bagi anak-anak dan remaja. Menurut Desmita (2011:219) "keluarga merupakan unit sosial yang terkecil yang memiliki peranan penting dan menjadi dasar bagi perkembangan psikososial anak dalam kontek sosial yang lebih luas. Seseorang anak akan dipengaruhi oleh sikap dan tindakan orang tuanya yang akan membentuk pribadi anak. Anak tidak hanya membutuhkan 
dukungan materil tetapi yang utama adalah pendidikan terbaik untuk masa depannya. Pendidikan terbaik dari orang tua dapat terlihat dari pola asuh yang diberikan.

Berdasarkan beberapa pendapat ahli yang membahas tentang lingkungan keluarga, lingkungan keluarga sangat berpengaruh untuk membentuk kepribadian seorang anak. Singkatnya, kepribadian seorang anak ditentukan dari kedua orang tuanya dan lingkungan sekitar. Begitupula ketika seorang anak memilih karir untuk masa depannya dukungan orang tua menentukan pilihan karirnya dan kesuksean dimasa depan. Berdasarkan teoriteori yang membahas lingkungan keluargamaka dapat disintesiskan bahwa lingkungan keluarga adalah tempat seseorang anak mendapatkan pendidikan pertama sejak dilahirkannya yang akan membentuk sikap dan tingkah laku seseorang hingga dewasa hingga pemilihan karier seseorang. Lingkungan keluarga diukur dibedakan menjadi dua macam yaitu lingkungan fisik dan non fisik, lingkungan non fisik berupa bimbingan orang tua, kasih sayang, dukungan orang tua, sosial ekonomi, dan lingkungan fisik meliputi sumber belajar dan fasilitas belajar.

\section{Efikasi diri}

Seseorang haruslah mempunyai efikasi diri atau biasa yang disebut dengan suatu keyakinan. Begitupula dengan seseorang yang ingin terjun ke bisnis atau berwirausaha. Seseorang yang ingin berwirausaha harus mempunyi efikasi yang tinggi atau mempunyai keyakinan atas kemampuannya seperti mempunyai ide kreatif yang menjadi modal utama dalam berwirausaha.

Efikasi diri atau Keyakinan diri mempunyai peran penting dalam setiap individu agar bisa menjalankan kehidupan yang baik. Keyakinan untuk menjadi pribadi yang baik dan yakin bisa meraih apa yang diinginkannya. Menurut Bandura yang dikutip 
oleh Nur Ghufron "Efikasi diri adalah keyakinan individu mengenai kemampuan dirinya dalam melakukan tugas atau tindakan yang diperlukan untuk mencapai hasil tertentu" (M. Nur Ghufron, 2010:73). Selanjutnya John W. Santrock (2011:21) menjelaskan efikasi diri adalah keyakinan bahwa seseorang menguasai situasi dan memberikan situasi hal yang positif. Selanjutnya menurut Gibson, James L. John M Ivancevich mengatakan "Efikasi diri adalah keyakinan bahwa seseorang dapat mengerjakan dengan cukup dalam situasi tertentu" (Wibowo, 2013:161).

Berdasarkan definisi efikasi diri di atas dapat diartikan bahwa efikasi diri adalah sebuah keyakinan yang ada dalam diri seseorang berdasarkan kemampuannya untuk melakukan sesuatu dengan berhasil. Efikasi diri sangatlah penting dimiliki setiap orang dengan adanya efikasi diri atau keyakinan yang ada pada diri seseorang maka seseorang tersebut termotivasi untuk melakukan sesuatu tindakan. Menurut Gist yang dikutip Danang menjelaskan "Efikasi diri adalah kepercayaan seseorang terhadap kemampuannya untuk melakukan tugas yang spesifik." Memperkuat pendapat Gist, Alwisol sampai pada kesimpulan bahwa efikasi diri adalah penilaian diri, apakah dapat melakukan tindakan yang baik atau buruk, tepat atau salah, bisa atau tidak bisa mengerjakan sesuai dengan yang diisyaratkan (Alwisol, 2004:360). Efikasi diri adalah kepercayaan diri untuk melakukan sesatu dengan baik karena percaya pada kemampuannya yang dinilainya akan berhasil dalam segala tindakannya. Efikasi diri bertindak sebagai awalan sebuah perilaku seseorang. Seseorang yang yakin bahwa dirinya akan berhasil di segala tugasnya maka akan benar-benar berhasil sampai tujuannya tercapai.

Menurut Bandura yang dikutip oleh Nur Gufron, efikasi diri 
pada tiap individu akan berbeda antara satu individu dengan yang lainnya berdasarkan tiga dimensi, berikut ini adalah tiga dimensi tersebut: (1) Dimensi Magnitude: Dimensi ini berkaitan dengan derajat kesulitan tugas ketika individu merasa mampu untuk melakukannya;

(2) Dimensi

Strength: Dimensi ini berkaitan dengan tingkat kekuatan dari keyakinan atau pengharapan individu mengenai kemampuannya; (3) Dimensi Generality: Dimensi ini berkaitan dengan luas bidang tingkah laku yang mana individu merasa yakin akan kemampuannya.

Sementara menurut Danang Sunyoto, self efficacy memiliki tiga dimensi yaitu: (1) Magnitude, tingkat kesulitan tugas yang dipercaya dapat dicapai seseorang. Dimensi magnitude dapat dibagi menjadi tiga yaitu pengharapan efficacy pada tingkat kesulitan tugas, analisis pilihan perilaku yang akan dicoba (merasa mampu melakukannya), serta menghindari situasi dan perilaku yang dirasakan melampaui batas kemampuan dirinya; (2) Strength, mengacu pada apakah hubungan mengenai magnitude kuat atau lemah. Strength dibagi menjadi dua, yaitu bertahan dalam usahanya dan keuletan dalam berusaha; Generality, mengindikasi tingkat harapan digeneralisasi pada situasi, dan (4) Generality juga dibagi menjadi dua yaitu pengharapan terbatas pada bidang perilaku khusus dan pengharapan yang menyebar pada berbagai bidanng perilaku.

Berdasarkan teori-teori yang membahas tentang efikasi diri maka dapat. Disintesiskan bahwa efikasi diri adalah keyakinan individu terhadap kemampuannya dalam melaksanakan tindakan untuk mencapai suatu tujuan individu yakni mampu untuk menghadapi segala tantangan dan mampu memprediksi seberapa besar usaha yang dibutuhkan untuk mencapai tujuan tersebut yaitu membuka usaha. Efikasi diri adalah keyakinan individu terhadap kemampuannya dalam melaksana- 
kan tindakan untuk mencapai suatu tujuan individu yakni mampu untuk menghadapi segala tantangan dan mampu memprediksi seberapa besar usaha yang dibutuhkan untuk mencapai tujuan tersebut yaitu membuka usaha. Efikasi diri dapat diukur pada Tingkat Kesulitan (Magnitude) yang mencerminkan mampu untuk berwirausaha, Optimis dalam mendirikan Usahanya, setelah itu Keyakinan diri (Strength) terdiri dari Yakin dengan keunggulan yang dimiliki, gigih Menyelesaikan tugas dan pengalaman (Generality) terdiri dari menjadikan pengalaman sebagai jalan mencapai kesuksesan dan menyikapi situasi yang berbeda dengan baik dan berpikir positif.

\section{METODOLOGI PENELITIAN}

Penelitian ini dilakukan dengan menggunakan metode expost facto dengan pendekatan kausal yang menggunakan data primer (variabel eksogen dan variabel endogen). Penelitian expost facto data yang diperoleh adalah data hasil dari peristiwa yang sudah berlangsung, sehingga peneliti hanya mengungkapkan fakta berdasakan pengukuran gejala yang telah ada. Penelitian ini dilakukan untuk menggali informasi mengenai seberapa besar pengaruh sosial ekonomi orang tua dan motivasi belajar terhadap minat melanjutkan studi ke perguruan tinggi. Populasi dalam penelitian ini adalah seluruh siswa kelas XI SMA Pusaka 1 Jakarta. Analisis data dalam penelitian ini dilakukan dengan menggunakan analisis jalur (path analysis).

Metode penelitian yang digunakan adalah metode ex post facto dengan pendekatan korelasional yang menggunakan data primer (variabel eksogen dan variabel endogen). Penelitian ex post de facto merupakan penelitian yang dilakukan setelah kejadian tersebut terjadi. Metode ini dipilih karena sesuai dengan tujuan penelitian yaitu untuk mengetahui seberapa besar pengaruh lingkungan keluarga $\left(X_{1}\right)$ dan efikasi diri $\left(X_{2}\right)$ sebagai variabel eksogen dengan motivasi berwirausaha $(\mathrm{Y})$ 
sebagai variabel endogen. Teknik pengumpulan data yang digunakan dalam penelitian ini menggunakan instrument berbentuk tes dan kuisoner (angket) yang memuat seperangkat daftar pertanyaan dan pernyataan yang dipersiapkan secara khusus. Kuisoner tersebut digunakan untuk mendapatkan data tentang variabel eksogen dan variabel endogen yaitu lingkungan keluarga (X1) dan efikasi diri (X2) dan motivasi berwirausaha sebagai (Y). Adapun analisis data dalam penelitian ini dilakukan dengan menggunakan analisis jalur (path analysis). Analisis jalur merupakan metode yang digunakan pada penelitian ini, metode tersebut dapat menentukan besarnya pengaruh suatu variabel terhadap variabel lainnya, baik pengaruh langsung maupun pengaruh tidak langsung.

\section{HASIL DAN PEMBAHASAN}

Berdasarkan hasil uji korelasi didapatkan angka sebesar 0, 581 . Nilai probabilitas $(\mathrm{sig})=0,000$. $(0,000<0,05)$. Karena sig $<0,05$ maka Ho ditolak dan Ha diterima.
Hal tersebut berarti terdapat hubungan yang signifikan positif antara variabel lingkungan keluarga terhadap motivasi berwirausaha. Dan angka 0,538 menunjukkan korelasi yang positif antara efikasi diri dengan motivasi berwirausaha. Selanjutnya diketahui nilai koefisien determinasi adalah di antarakan 0 dan 1. Nilai koefisien determinasi yag besar berarti kemampuan variabel $X_{1}$ dalam menjelaskan variabel $X_{2}$ memberikan hampir semua informasi yang dibutuhkkan. Adapun nilai Rsquare variabel Lingkungan keluarga adalah sebesar 0,145. Hal ini berarti 14,5\% artinya lingkungan keluarga memberikan kontribusi terhadap efikasi diri sebesar 14,5\% sedangkan sisanya dipengaruhi oleh factor lain. variabel efikasi diri $\left(X_{2}\right)$ dapat dijelaskan oleh variabel lingkungan keluarga $\left(X_{1}\right)$. Sehingga sisanya (error) dipengaruhi oleh variabel lain yang merupakan faktorfaktor yang ada dalam penelittian ini. dengan demikian error $(\varepsilon)=1$ $R^{2}=1-0,145=0,855$. 
Berdasarkan perhitungan dan pengujian di dapat Fhitung $=12,163$ ; df1=1; df2=72, p-value =0,001< 0,05 atau Ho ditolak nilai $p$-value Fhitung 0,001 (< 0,05), maka Ho ditolak. Dengan demikian, variabel Lingkungan keluarga $\left(\mathrm{X}_{1}\right)$ berpengaruh terhadap variabel efikasi diri $\left(X_{2}\right)$. Berdasarkan hasil pengujian secara individual lingkungan keluarga terhadap efikasi diri didapat nilai signifikan sebesar 0,001, maka nilai (sig) $0,001<0,05$ dengan demikian $\mathrm{Ho}$ ditolak dan $\mathrm{Ha}$ diterima. Itu artinya koefisien jalur signifikan, sehingga dapat disimpulkan bahwa lingkungan keluarga berpengaruh secara signifikan terhadap efikasi diri.

Hasil uji $t$ diperoleh $t_{\text {hitung }}$ dari lingkungan keluarga sebesar 3,488. Pengujian ini sifatnya dua arah, sebab proposisi hipotetik tidak mengisyaratkan apakah pengaruh $\mathrm{X}_{1}$ terhadap $\mathrm{X}_{2}$ merupakan pengaruh positif atau negative. Untuk $t_{\text {tabel }}$ dapat dicari pada tabel tingkat signifikansi 0,05 dengan $\mathrm{df}=$ $\mathrm{n}-\mathrm{k}-1 . \quad 74-1-1=72$ maka $\mathrm{t}_{\text {tabel }}$ sebesar 1,669. Oleh karena itu maka diketahui bahwa $t_{\text {hitung }}$ lingkungan keluarga $>t_{\text {tabel, }}$ yakni $3,488>1,669$, artinya Ha diterima Ho ditolak. Hal tersebut berarti bahwa lingkungan keluarga berpengaruh positif dan signifikan terhadap efikasi diri.

Berdasarkan hasil output SPSS didapat hasil Beta adalah 0,581. Hal ini berarti terdapat pengaruh langsung $X_{1}$ terhadap $Y$ sebesar 0,581. Selanjutnya dari tabel Coefficient diperoleh harga $t_{\text {hitung }}=6,062$ dan $p$-value $=0,000$. P-value merupakan probabilitas yang mengasumsikan bahwa hipotesis nol adalah benar. Hasilnya adalah $p$-value <0,005. Hal ini berarti nilai probabilitas Sig lebih kecil dari nilai probabilitas 0,05 artinya Ho ditolak dan Ha diterima, dengan demikian variabel lingkungan keluarga $\left(\mathrm{X}_{1}\right)$ berpengaruh langsung positif dan signfikan terhadap motivasi berwirausaha $(Y)$ sebesar 0,581 .

Pada output SPSS didapat nilai Beta sebesar 0,538. Hal ini berarti terdapat pengaruh langsung 
$\mathrm{X}_{1}$ terhadap $\mathrm{Y}$ sebesar 0,581 . Selanjutnya dari tabel Coefficient diperoleh harga thitung $=5,419$ dan $p$ value $=0,000$. P-value merupakan probabilitas yang mengasumsikan bahwa hipotesis nol adalah benar.Hasilnya adalah $p$-value < 0,005. Hal ini berarti nilai probabilitas Sig lebih kecil dari nilai probabilitas 0,05 artinya Ho ditolak dan Ha diterima, dengan demikian variabel efikasi diri $\left(\mathrm{X}_{2}\right)$ berpengaruh langsung positif dan signfikan terhadap motivasi berwirausaha $(\mathrm{Y})$ sebesar 0,538.

Berdasarkan hasil penelitian dan proses perhitungan yang telah dilakukan terhadap 74 mahasiswa Fakultas Ekonomi Universitas Negeri Jakarta mengenai pengaruh lingkungan keluarga dan efikasi diri terhadap motivasi berwirausaha, maka diperoleh perhitungan koefisien jalur dan didapat $(\mathrm{Y})=$ $0,581 X_{1}+0,538 X_{2}+0,544^{\varepsilon}$ artinya persamaan ini menjelaskan bahwa nilai koefisien jalur $X_{1}$ sebesar 0,581 yang berarti lingkungan keluarga $\left(X_{1}\right)$ bertambah
1 poin maka motivasi berwirausaha $(\mathrm{Y})$ akan meningkat 0,581 poin.

Berdasarkan uji hipotesis yang dilakukan maka hasil analisiis korelasi antara lingkungan keluarga dan efikasi diri dengan motivasi berwirausaha diperoleh hasil pengaruh langsung positif dengan nilai (sig) sebesar 0,001 Nilai ini memberikan pengertian bahwa ada hubungan positif yang kuat anntara lingkungan keluarga dan efikasi diri dengan motivasi berwirausaha. Semakin baik lingkungan keluarga akan mempengaruhi efikasi diri maka semakin tinggi motivasi untuk berwirausaha. Demikian pula sebaliknya, semakin buruk lingkungan keluarga dan efikasi diri semakin rendahnya motivasi untuk berwirausaha pada mahasiswa.

Besarnya kontribusi variabel motivasi berwirausaha ditentukan oleh variabel lingkungan keluarga dan efikasi diri, yang dapat diketahui dari hasil $R^{2}$ pyx $_{1} x_{2}$ sebesar 0,544 . Secara statistic nilai ini memberikan pengertian bahwa kurang dari $54,4 \%$ varian motivasi berwirausaha ditentukan atau dipengaruhi oleh 
lingkungan keluarga dan efikasi diri, sisanya sebesar $54,4 \%$ ditentukan faktor lain.

Berdasarkan hasil perolehan statistic secara individual $X_{1}$ terhadap $Y$ diperoleh hasil coefficients Beta sebesar 0,581. Dengan demikian variabel lingkungan keluarga $\left(X_{1}\right)$ berpengaruh langsung positif dan signifikan terhadap moivasi berwirausaha $(\mathrm{Y})$ sebesar 0,581 satuan. Selanjutnya berdasarkan hasil perolehan statistic secara individual $\mathrm{X}_{2}$ terhadap $\mathrm{Y}$ diperoleh hasil Coefficients Beta sebsear 0,538 dengan demikian variabel efikasi diri $\left(X_{2}\right)$ berpengaruh langsung positif dan signifikan terhadap motivasi berwirausaha $(\mathrm{Y})$ sebesar 0,538. Untuk struktur ke tiga berdasarkan hasil statistic secara individual $X_{1}$ terhadap $X_{2}$ sebesar 0,380 , dengan demikian variabel lingkungan keluarga yang menjadi $X_{1}$ berpengaruh langsung postif dan signifikan terhadap efikasi diri sebesar 0,380.

Hasil penelitian ini memperkuat temuan Siti Rochmah Maulida (2012). Menurut Siti
Rochmah berdasarkan analisis data terhadap hubungan antara kepercayaan diri dan dukungan orang tua dengan motivasi berwirausaha pada siswa SMK diketahui bahwa koefisien regresi sebesar 0,481 $(p<$ 0,01 ) ini berarti ada hubungan yang sangat signifikan antara kepercayaan diri dan dukungan orang tua dengan motivasi berwirausaha pada siswa SMK.

\section{KESIMPULAN DAN SARAN}

Berdasarkan hasil penelitian mengenaai pengaruh lingkungan keluarga dan efikasi diri terhadap motivasi berwirausaha mahasiswa Fakultas Ekonomi Jurusan Ekonomi dan Adminstrasi Universitas Negeri Jakarta, maka dapat disimpulkan sebagai berikut: (1) Lingkungan keluarga $\left(X_{1}\right)$ yang diukur oleh motivasi berwirausaha $(Y)$ memiliki kontribusi yang positif dan signifikan terhadap tinggi rendahnya motivasi berwirausaha. Besarnya kontribusi lingkungan keluarga secara langsung terhadap motivasi berwirausaha adalah sebesar $58,1 \%$. Artinya semakin baik 
lingkungan keluarga untuk mendukung anak memilih karier sebagai wirausaha maka motivasi berwirausaha pun akan meningkat. Berdasarkan hasil penelitian ini dapat disimpulkan bahwa hipotesis penelitian yang menyatakan bahwa lingkungan keluarga berpengaruh secara langsung terhadap motivasi berwirausaha; (2) Efikasi diri $\left(\mathrm{X}_{2}\right)$ yang diukur oleh motivasi berwirausaha (Y) memiliki kontribusi yang positif dan signifikan terhadap tinggi rendahnya motivasi berwirausaha. Besarnya kontribusi efikasi diri secara langsung terhadap motivasi berwirausaha sebesar 53,8\%. Artinya, semakin tinggi tingkat efikasi diri atau keyakinan atas kemampuan yang dimilikinya untuk memulai berwrausaha maka akan meningkat pula motivasi berwirausaha. Dengan demikian dapat disimpulkan bahwa hipotesis bahwa efikasi diri berpengaruh secara langsung terhadap motivasi berwirausaha.

Lingkungan keluarga secara langsung berpengaruh pada efikasi diri seorang anak. Dengan demikian tinggi rendahnya efikasi diri dijelaskan oleh lingkungan keluarga. Besarnya kontribusi lingkungan keluarga secara langsung terhadap efikasi diri sebesar 38\%. Artinya, semakin lingkungan keluarga yang dibina maka akan mempengaruhi tumbuhnya efikasi diri, yaitu keyakinan atas kemampuan yang dimilikinya

\section{Berdasarkan kesimpulan} yang dikemukakan di atas, saransaran yang kiranya dapat diberikan peneliti adalah: (1) Dalam meningkatkan motivasi berwirausaha pada mahasiswa Fakultas Ekonomi, dari lingkungan keluarga hendaknya memberikan dukungan untuk memilih karir sebagai wirausaha dengan cara: (a) Orang tua hendaknya memberikan arahan kepada anak dalam berwirausaha, misalnya seperti meningikuti pelatihan keterampilan (kursus). Dengan keerampilan yang baik, maka dapat meningkatkan kemajuan dalam berwirausaha adalah salah satu pekerjaan yang menjanjikan di masa yang akan 
datang. Mengajarkan tentang cara memulai berwirausaha, menanamkan nilai nilai jiwa wirausaha sejak dini; (b) Pihak Fakultas Ekonomi sebaiknya ikut berkontribusi untuk menumbuhkan keluarga yang mendukung anaknya berwirausaha dengan cara membuat perkumpulan orang tua mahasiswa Fakultas Ekonomi dengan memberikan seminar-seminar kewirausahaan. (2) Untuk meningkatkan motivasi berwirausaha dengan efikasi pada diri seseorang atau keyakinan atas kemampuan yang dimilikinya dengan cara: (a) Sebaiknya menanamkan jiwa optimis untuk memulai berwirausaha. Mencoba percaya pada kemampuan diri dan berpikir positif; (b) Pihak Fakultas Ekonomi membuat suatu proram kewirausahaan yang memberikan modal awal kepada mahasiswa Fakultas Ekonomi yang ingin mencoba berwirausaha dengan cara ini mahasiswa menjadi yakin mencoba berwirausaha, dan (3) Untuk meningkatkan motivasi berwirausaha pada mahasiswa Fakultas Ekonomi dengan cara: (a)
Pihak Fakultas Ekonomi sebaiknya lebih sering membuat acara talk show atau seminar-seminar untuk mengajak mahasiswa dalam berwirausaha. menggali kemampuan yang dimilikinya, menjadikan matakuliah kewirausahaan sebagai matakuliah yang wajib diikuti mahasiswa Fakultas Ekonomi dan lebih sering membuat bazaar berjualan yang wajib diikuti mahasiswa Fakultas Ekonomi setiap tahunnya, dan (b) Untuk meningkatkan efikasi diri diperlukan lingkungan yang mendukung atau lingkungan yang baik bagi fase perkembang seorang anak. Peran orang tua atau lingkungan keluarga sangat besr dalam membentuk selfefficacy atau efikasi diri pada setiap anaknya. Dengan cara diajarkan untuk percaya diri, pekerja keras dan tidak pantang menyerah.

\section{DAFTAR PUSTAKA}

Arikunto, Suharsimi. (2007). Manajemen Penelitian. Jakarta: Rineka Cipta. . (2012). Dasar-dasar Evaluasi Pendidikan. Jakarta: Bumi Aksara. 
Ahmadi, Abu. (2003). Psikologi Umum. Jakarta: PT. Rineka Cipta.

Baraja, Abubakar. (2005). Psikologi Perkembangan. Jakarta: Perpustakaan Nasional.

Baron, Robert. (2003). Psikologi Sosial. Jakarta: Erlangga.

Bernandid, Imam.

(1999).

Pengantar Ilmu Pendidikan

Sistematis. Yogyakarta: Andi Offset.

Buchari, Alma. Kewirausahaan untuk (2011). Mahasiswa dan umum. Bandung: Alfabeta.

Bahri, Syaiful. (2002). Psikologi Belajar. Jakarta: PT. Rineka Cipta.

Danim, Sudarwan. (2004). Motivasi Kepemimpinan dan efektivitas kelompok. Jakarta: PT. Rineka Cipta.

Desmita. (2011). Psikologi Perkembangan Peserta Didik. Bandung: PT. remaja Rosdakarya. 2011.

Elly, M Setiadi. (2012). Ilmu Sosial \& Budaya Dasar. Jakarta: Kencan.

Fahmi, Irham. (2013). Kewirausahaan: Teori, Kasus dan solusi. Bandung: Alfabeta.

Kasmir. (2011). Kewirausahaan. Jakarta: PT. Grafindo Persada.

Kreitner Robert dan Angelo Kinicki. (2004). Organizational Behavior. New York: McGraw Hill.

Luthans, Fred. (2006). Perilaku organisasi. Yogjakarta: CV. Andi.
Meredith,Geoffrey (2000). Kewirausahaan: Teori dan Praktek. Jakarta: Erlangga.

Nasution, Arman Hakim. (2007). Entrepreneurship Membangun Spirit. Yogyakarta: CV. Andi.

P, Robbins Stephen. (2003). Perilaku Organisasi. Jakarta: PT. Indeks.

Saiman, Leonardus. (2009). Kewirausahaan: Teori, Praktik dan Kasus-kasus. Jakarta Salemba Empat.

Sunyoto, Danang. (2013). Perilaku Organisasional. Yogyakarta: CAPS.

Sumarsono, Sonny. (2010). Kewirausahaan. Yogyakarta: Graha IImu.

Sudaryono. (2011). Kewirausahaan. Jogyakarta: CV. Andi.

Suryana. (2006). Kewirausahaan: Pedoman Praktis, kiat dan Proses Menuju Sukses. Jakarta: Salemba Empat.

Maulida Siti Rochmah dan Dhini Rahma. (2012). Hubungan antara Kepercayaan diri dan Dukungan orang tua dengan motivasi berwirausaha pada siswa SMK. Jurnal: Universitas Diponogoro, vol 5. 